\title{
Correlation between Different Traits of Personality among Monozygotic Twins
}

\author{
Poonam Rani* and Bimla Dhanda
}

\author{
Department of Human Development and Family Studies, I.C. College of Home Science, \\ CCSHAU, Hisar, Haryana - 125004, India \\ *Corresponding author
}

\begin{tabular}{|l|}
\hline Ke y w o r d s \\
$\begin{array}{l}\text { Correlation, } \\
\text { Consciousness, } \\
\text { Traits, Monozygotic } \\
\text { Twins }\end{array}$ \\
\hline Article Info \\
\hline $\begin{array}{l}\text { Accepted: } \\
18 \text { August } 2018 \\
\text { Available Online: } \\
\text { 10 September } 2018\end{array}$ \\
\hline
\end{tabular}

\section{A B S T R A C T}

Personality traits, which can be described as differences between individuals regarding their behavior, thoughts, and feelings, can be seen as relatively stable in different situations and over time (Specht et al., 2014). A pair of 90 twins in the age group of 3-6 years from five cultural zones of state Haryana was taken. A Five Factor Personality Questionnaire (Cathy, 2011) was used for assessing the personality traits of preschool twins. Pearson correlation test was applied to see the correlations of personality traits among monozygotic twins, and the results are portrayed that agreeableness of children had negative and significant correlations with extraversion $(r=-0.32 *)$ except consciousness $(r=-0.12)$ and openness $(\mathrm{r}=-0.14)$ which was negative but non- significant correlated agreeableness. Extraversion was positive and significant correlation with consciousness $(r=0.39 *)$ and openness $\left(r=0.44^{*}\right)$ but neuroticism was positive and non-significant correlations with extraversion. Neuroticism was positive and significant correlations with consciousness $(\mathrm{r}=0.32 *)$ and openness $(\mathrm{r}=0.33 *)$. Consciousness was positive and significant correlations with openness $\left(\mathrm{r}=0.43^{*}\right)$. Openness was positive and significant correlations with extraversion $\left(r=0.44^{*}\right)$, neuroticism $\left(r=0.33^{*}\right)$ and consciousness $\left(r=0.43^{*}\right)$ but was negative and significant correlations with agreeableness $\left(\mathrm{r}=-0.14^{*}\right)$.

\section{Introduction}

Personality is a patterned body of habits, traits, attitudes and ideas of an individual as these are organized externally into roles and statuses and as they relate internally to motivation, goals and various aspects of selfhood (Sareen, 2015).

Personality has been approached in quite different ways by many theorists. Freud proposed that personality development is dependent upon early childhood experiences and largely determined by age five (Carver and Scheier, 2008). There is no doubt that early experience influences later development but this influence could account for individual differences in many aspects such as cognition, socio- emotional skills and personality (Malekpour, 2007).

The first of the five factors is extraversion. Extraversion is an energetic approach toward the social and material world and includes traits such as sociability, activity, 
assertiveness, and positive emotionality. Extraversion is often thought of as implying sociability (Ashton et al., 2002). Some see a sense of agency and a sense of sociability as two facets of extraversion (Depue et al., 2005). Others argue sociability is a by-product of other features of extraversion (Lucas et al., 2000).

The second factor, neuroticism, concerns the ease and frequency with which a person becomes upset and distressed. Neuroticism, "contrasts emotional stability and even temperedness with negative emotionality, such as feeling anxious, nervous, sad, and tense; has been linked to the avoidance temperament (Evans and Rothbart, 2007). The next factor is agreeableness. Agreeableness "contrasts a prosocial and communal orientation toward others with antagonism and includes traits such as altruism, tender-mindedness, trust, and modesty. Agreeable people are friendly, helpful and empathic (Graziano et al., 2007). Age-related declines in neuroticism and increases in agreeableness and conscientiousness (McCrae et al., 2000).

The most commonly used label for the next factor is conscientiousness, refers to "socially prescribed impulse control that facilitates taskand goal-directed behavior, such as thinking before acting, delaying gratification, following norms and rules, and planning, organizing, and prioritizing tasks.

Agreeableness and conscientiousness appear both suggest breadth of perspective. Many manifestations of conscientiousness imply broad time perspective that is taking future contingencies into account. Agreeableness implies a broad social perspective counting taking the needs of others into account. It has been suggested that both of these traits have origins in the effortful control temperament (Jensen-Campbell et al., 2002). The fifth factor, most often called openness to experience involves curiosity, flexibility, imaginativeness, and willingness to immerse oneself in atypical experiences such as involvement in social experience. Openness is the breadth, depth, originality, and complexity of an individual's mental abilities (John and Sotto, 2008).

The present study aim is to find out the correlation between different traits of personality among monozygotic twins.

\section{Materials and Methods}

The study was conducted in five cultural zones of Haryana state namely Khadar, Bagar, Nardak, Mewat and Ahirwal. A pair of 90 twins (180 twins) in the age group of 3-6 years from different villages was assessed depending upon the availability of the twins were taken as sample. The present study aim is to find out the correlation between different traits of personality among monozygotic twins. A Five Factor Personality Questionnaire (Cathy, 2011) was used for assessing the personality traits of monozygotic twins.

\section{Results and Discussion}

\section{Correlations between personality traits among monozygotic twins}

Pearson correlation test was applied to see the correlations of personality traits among monozygotic twins, and the results are portrayed that agreeableness of children had negative and significant correlations with extraversion $(\mathrm{r}=-0.32 *)$ except consciousness $(\mathrm{r}=-\mathrm{-0.12})$ and openness $(\mathrm{r}=-0.14)$ which was negative but non- significant correlated agreeableness. Extraversion was positive and significant correlation with consciousness ( $r=$ $0.39 *)$ and openness $(\mathrm{r}=0.44 *)$ but neuroticism was positive and non-significant correlations with extraversion. Neuroticism 
was positive and significant correlations with consciousness $(\mathrm{r}=0.32 *)$ and openness $(\mathrm{r}=0.33 *)$. Consciousness was positive and significant correlations with openness $\left(\mathrm{r}=0.43^{*}\right)$. Openness was positive and significant correlations with extraversion $(\mathrm{r}=$ $0.44 *)$ neuroticism $\left(\mathrm{r}=0.33^{*}\right)$ and consciousness $\left(\mathrm{r}=0.43^{*}\right)$ but was negative and significant correlations with agreeableness $(\mathrm{r}=-0.14 *)$. Personality traits are defined as the relatively enduring patterns of thoughts, feelings, and behaviors that differentiate individuals from one another and are elicited in trait affording situations (Roberts, 2009).

Extraversion trait had significant correlations with all traits namely; agreeableness, consciousness and openness except neuroticism. Extraversion and agreeableness act as protective factors whereas neuroticism may act as a risk factor Jianing et al., (2016) (Table 1).

Table.1 Correlations between personality traits among monozygotic twins $(\mathrm{N}=180)$

\begin{tabular}{|l|c|c|c|c|c|}
\hline \multicolumn{5}{|c}{ Correlations between personality traits among monozygotic twins } \\
\hline Traits & Agreeableness & Extraversion & Neuroticism & Consciousness & Openness \\
\hline Agreeableness & 1.00 & $-0.32^{*}$ & 0.02 & -0.12 & -0.14 \\
\hline Extraversion & & 1.00 & 0.05 & $0.39^{*}$ & $0.44^{*}$ \\
\hline Neuroticism & & & 1.00 & $0.32^{*}$ & $0.33^{*}$ \\
\hline Consciousness & & & & 1.00 & $0.43^{*}$ \\
\hline
\end{tabular}

*Significant at $5 \%$ level of significance

The psychobiological theory of personality (Cloninger, 2008) suggested that personality is composed of temperament and character; two inter-related domains regulate the development of human psychological functions.

Fink et al., (2005) suggested that a possible correlate of personality, especially for openness, extraversion and agreeableness, but did not find the predicted positive associations between them. Both the traits namely; neuroticism and extraversion trait were significantly correlated across various cultures (McCrae, 2002).

Prenda and Lachman (2001) found significant and positive correlations between agreeableness, conscientiousness, openness, and extraversion but significant and negative correlations between neuroticism and the other four personality traits. Research has demonstrated a moderate to high correlations between extraversion and neuroticism personality traits in different cultures (Oishi, 2002).

\section{References}

Ashton, M. C., Lee, K. and Paunonen, S. V. 2002. What is the central feature of extraversion? Social attention versus reward sensitivity. Journal of Personality \& Social Psychology, 83:245-52.

Benjamin, J., Ebstein, R., and Belmaker, R. H. 2002. Molecular genetics of human personality. Washington, DC: American Psychiatric Press. Behavioral Scientist, 44:10-31.

Carver, C.S. and Scheier, M. F. 2008. Perspectives on Personality. Boston, MA: Allyn \& Bacon. 6th ed.

Cloninger, C.R., 2008. The psychobiological theory of temperament and character: Common on Farmer and Goldberg. Psychological Assessment, 20: 292-299.

Depue, R. A. and Morrone-Strupinksy, J. V. 
2005. A neurobehavioral model of affiliative bonding: implications for conceptualizing a human trait of affiliation. Behavior Brain Science, 28:313-395.

Evans, D. E. and Rothbart, M. K. 2007. Developing a model for adult temperament. Journal of Research Personality, 41:868-888.

Fink, B., Neave, N., Manning, J. T. and Grammer, K. 2005. Facial symmetry and the 'big-five' personality factors. Personality and Individual Differences, 39:523-529.

Graziano, W. G., Habashi, M. M., Sheese, B. E. and Tobin, R. M. 2007. Agreeableness, empathy, and helping: a person X situation perspective. Journal Personality Social Psychology, 93:58399.

Jensen-Campbell, L. A., Adams, R., Perry, D. G., Workman, K. A., Furdella, J. Q. and Egan, S. K. 2002. Agreeableness, extraversion, and peer relations in early adolescence: winning friends and deflecting aggression. Journal of Research Personality, 36:224-51.

Jianing, Y., Min-Pei, L., Sian, X. and WeiHsuan, H. 2016. Big Five personality traits in the occurrence and repetition of nonsuicidal self-injury among adolescents: The mediating effects of depressive symptoms. Personality and Individual Differences, 101: 227-231.

John, O.P., Naumann, L. P. and Soto, C. J. 2008. Paradigm shift to the integrative Big- Five trait taxonomy: History, measurement, and conceptual issues. In O. P. John, R. W. Robins, \& L. A. Pervin (Eds.), Handbook of personality: Theory and research (114-158). New York: Guilford Press.

Lamb, M. E., Chuang, S. S., Wessels, H., Broberg, A. G. and Hwang, C. P. 2002. Emergence and construct validation of the Big Five factors in early childhood: a longitudinal analysis of their ontogeny in Sweden. Child Development, 73:1517-24.

Lucas, R. E., Diener, E., Grob, A., Suh, E. M. and Shao, L. 2000. Cross-cultural evidence for the fundamental features of extraversion. Journal of Personality \& Social Psychology, 79:452-68.

Malekpour, M. 2007. Effects of attachment on early and later development. The British Journal of Developmental Disabilities, 53(105): 81-95.

McCrae, R. R. 2002. Cross-Cultural Research on the Five-Factor Model of Personality. Readings in Psychology and Culture, 4(4):1-12.

McCrae, R. R. 2002. Cross-Cultural Research on the Five-Factor Model of Personality. Readings in Psychology and Culture, 4(4):1-12.

Oishi, S. 2002. The experiencing and remembering of well-being: Acrosscultural analysis. Personality and Social Psychology Bulletin, 28:1398-1406.

Prenda, K. M. L and Achman, M. E. 2001. Planning for the future: A life management strategy for increasing control and life satisfaction in adulthood. Psychology and Aging. 16(2): 206-216.

Robert, P. C., Haworth, M. A. and Philip, D. 2008. A Twin Study into the Genetic and Environmental Influences on Academic Performance in Science in nine-year-old Boys and Girls. International Journal of Science Education. 30(8): 1003.

Roberts, B.W. 2009. Back to the Future: Personality and Assessment and personality development. Journal of Research in Personality. 43:137-145.

Sareen, S. 2015. Johari Window: An Important Model for Personality Development. Gene -International Journal of Management Research. 3(4):13-18. 
Specht J., Bleidorn W., Denissen J. J. A., Hennecke M., Hutteman R. and Kandler C. 2014. What drives adult personality development? A comparison of theoretical perspectives and empirical evidence. European Journal of
Personality, 28: 216-230.

Terracciano, A., Costa, P. T. and McCrae, R. R. 2006. Personality plasticity after age 30. Personality and Social Psychology Bulletin, 32:999-1009.

\section{How to cite this article:}

Poonam Rani and Bimla Dhanda. 2018. Correlation between Different Traits of Personality among Monozygotic Twins. Int.J.Curr.Microbiol.App.Sci. 7(09): 2803-2807.

doi: https://doi.org/10.20546/ijcmas.2018.709.348 